\title{
The Mosaics of National Identity in the Arab American Diaspora: Exploring Long-Distance Nationalism in Diana Abu-Jaber's Crescent
}

\author{
Ishak Berrebbah \\ Coventry University
}

\begin{abstract}
Carol Fadda-Conrey (2014) points out that Arab American literature emerged remarkably in the early years of the 21 st century, accompanying various political events and turmoil in either the USA or the Arab world, particularly the Middle East. One of the key aspects of this ethnic literature is the manifestation of the Arab national identity and the call for unity and solidarity among kin Arab communities, whether locally or across borders. This paper, as such, by taking Diana Abu-Jaber's novel Crescent (2003) as an example of the Arab American fiction produced in the contemporary era, examines the components of nationalism as expressed from afar - long-distance nationalism. This type of national propensity has received little attention in contemporary literary studies. In addition to using critical and analytical approaches to the novel, this paper basically relies on a socioconceptual framework based on the perspectives of prominent theorists and critics, such as Carol Fadda-Conrey, Nina Glick Shiller, Gabriella Elgenius, and Tololyan Khachig, to name a few.
\end{abstract}

\section{Keywords}

Arab American; Crescent; Diana Abu-Jaber; diaspora; long-distance nationalism; identity

National ideology, national culture and national hopes do indeed go on, coexisting with increasing transnational realities.

Chantal Bordes-Benayoum (2010, 52)

The term nationalism, in its broader sense, refers to either an "attitude that the members of a nation have when they care about their national identity or the actions that the members of a nation take when seeking to achieve self-determination" (Miscevic 2018). In another sense, nationalism is "a set of

\footnotetext{
* Ishak Berrebbah, Faculty of Arts and Humanities, Coventry University, Coventry CV1 5FB, United Kingdom; berrebbi@uni.coventry.ac.uk. ORCID: https://orcid.org/0000-0002-4355-2214.
} 
beliefs and practices that link together the people of a nation and its territory" (Schiller and Fouron 2001, 17-18). It is, in Peter Wien's terms, "a cultural reference system that creates belonging" $(2017,2)$. This system is referred to in a "diasporic" context as "diaspora nationalism" (Landau 2001). This sort of nationalism from afar is primarily identified as long-distance nationalism. It mainly concerns diasporans and is a key feature of many diasporic identities, as Schiller (2005) argues. This type of nationalism is multidimensional and part of the process of reconnection with the homeland, reflecting a transnational agenda. It was first coined by the historian and anthropologist Benedict Anderson (1994, 1998): according to him, long-distance nationalism is a form of transnational activity and identity that concerns migrants and exiles. It is a practice and an ideology that sets up a bond between those who migrated and those who stayed behind in the homeland and shared cultural and national ties. In other words, in Schiller and Fouron's terms, this type of nationalism "binds together immigrants, their descendants, and those who have remained in their homeland into a single transborder citizenry" $(2001,20)$.

The notion of long-distance nationalism, to a large extent, concerns the Arab American community, whose members engage with nationalist ideologies and practices to maintain a bond with the Arab nation in other geographical parts of the world, including their homelands. This ethnic minority also forms what is known as "ethnonationalism". It refers to "a form of organizing around perceived similarities of culture, religion or ethnicity" (Salaita 2011, 45). This means that the Arab nationalist vision in the USA establishes a connection with both local ethnic members and those settled abroad, given that they share an Arab identity. Steven Salaita, however, in his critique of Rabih Alameddine's Koolaids, refers to ethnonationalism as a notion that can be limited, pejorative, decentralized, and problematic in that some members of the same ethnic group - such as Lebanese - may apply it in a way that serves heterogeneity and disconnection from those who have different characteristics and criteria, and national claims (2011, 45-46). For instance, while some characters of Lebanese origin in Koolaids regard Lebanon as a part of Western culture, others of the same ethnic origin regard it as a part of the Arab and Muslim world. This shows that the various perceptions of nationalism and its metrics add more complexity to the defining process of ethnic identity, especially the Arab identity.

Arab nationalism in the US diaspora, borrowing Schiller's words, denotes a perspective that "there is a nation that consists of a people who share a common history, identity, and territory" (Schiller 2005, 571). It should be acknowledged, in this context, that long-distance nationalism has received 
little attention in diaspora literary studies, especially in contemporary Arab American fiction. It has primarily been tackled in sociology and political sciences. The value of studying long-distance nationalism in literary texts, particularly fiction, will broaden the horizons in defining this term and help to understand its various interpretations. Exploring this type of nationalism is as important in literature as in sociology and political sciences.

Diana Abu-Jaber introduces us to the factors that construct nationalism in the diaspora, reflecting on the Arab American community as narrated in her novel Crescent (2003). She suggests that, on the one hand, the nature of Arab nationalism - as being expressed from afar - contributes to the formation of the Arab identity and the confirmation of belonging to the Arab nation. On the other hand, it provides new understandings of the Arab Americans' affiliation to US citizenship and their integration with the social mainstream. In other words, in Fadda-Conrey's terms, "the discursive negotiation of transnational connections to Arab homelands from a variegated and multilayered US perspective has an integral role in creating a space for reformulating hegemonic and unilocal understandings of US citizenship and belonging" $(2014,3)$.

The novel Crescent mainly revolves around two protagonists: Hanif El Eyad, known as Han, and Sirine. The former is an Iraqi professor of linguistics and Arabic literature at a well-established university in the city of Los Angeles. While carrying the pain of being an exiled person, he desperately endeavors to locate himself inside the new environment of the USA. The latter is a 39-yearold woman, who is an Iraqi American and works as a chef at Um-Nadia's Café, an Arab restaurant located in a Los Angeles neighborhood called Tahrangeles. The novel, given that most of its narratives are told in the setting of the diaspora from Sirine's uncle's point of view, mirrors several perspectives based on nationalism and national identities. The analysis of Crescent in this paper aims at answering the following questions: How does Abu-Jaber identify her Arab national identity in her novel? What constitutes longdistance nationalism in the Arab American diaspora? The reading of AbuJaber's Crescent will provide multiple but complex insights into how diasporic figures negotiate and project their nationalist affiliations and tendencies.

\section{Long-Distance Nationalism and Its Political Connotations: A Critique of the US Foreign Policy in the Arab World}

Abu-Jaber projects her long-distance Arab nationalistic beliefs in the novel by critiquing US imperial ambitions in the Arab world and narrating a rejection of US policy in the Middle East, particularly Iraq. She presents her novel as 
a political project. This shows that "long-distance nationalism has fostered diasporas' active engagement in oppositional politics" (Um 2019, 329). Politics, especially those that concern the Middle East, is the main subject discussed in the Café. Politics bothers Um-Nadia because it is frequently and enthusiastically discussed: "why does it always have to be politics and fighting with you people!" $(2003,222)$. It is worth trying to understand why Um-Nadia in this scene is turned off by these political discussions. One major explanation is that such conversations are triggered daily, constantly, and frequently. They become a verbal routine in the Café. Being bothered, however, does not mean that Um-Nadia is not interested in politics - she always makes sure to bring in Arabic journals of politics and tune the television into Arabic channels to be updated on the latest events in the Arab world, particularly the Middle East, including her country of origin Lebanon, which witnessed a political turmoil in the 1990s.

Abu-Jaber suggests that there is a strong transnational connection between the members of the Arab American community and the Arab nation abroad. The rise and spread of Arab nationalism in the mid-20th century entailed political engagements both in Arab countries and in the diaspora, as FaddaConrey argues:

The rising Arab nationalisms of the 1950s and 1960s, as well as the increasing imperial ambitions of the US in the Arab world during the second half of the twentieth century onward, galvanized stronger transnational political attachments to the Arab world among ArabAmerican communities across the US. As a result, new trans-Arab solidarities were formed (both within the US and between the USbased Arab diaspora and the Arab world) that were driven by particular political and Arab nationalist concerns while still being firmly grounded in the US geopolitical terrain $(2014,13)$.

Indeed, Crescent presents such trans-Arab solidarity and political engagement as expressed by Arab American characters. For instance, Rana, a daughter of a Saudi father and American mother, demonstrates much of Fadda-Conrey's arguments when she says:

Nine full years after the war - it's the total destruction of Iraq's economy and people...targeting women and children...the American embargoes... biological weapons, rocket launchers, nerve gas [...] American Muslims must do everything they can to show support for their Iraqi brothers and sisters. We can demonstrate, write to Congress (2003, 190).

Rana's nationalistic intervention appeals to the audience to collectively detest the American political and military actions in the Gulf countries, particularly in Iraq and its capital Baghdad, which is perceived by her as "the mother of the 
whole Arab world" (2003: 187). Rana's stance, while being a member of the Arab American community, suggests that "diasporas are resolutely multilocal and polycentric, in that what happens to kin communities in other areas of dispersions as well as in the homeland insistently matters to them" (Tololyan 2007, 651). These types of diasporans, in Schiller's terms, "may be or become long distance nationalists and take actions to obtain, defend, or support political action in a specific territory that they designate as home" $(2005,571)$. Rana's intervention, however, gets an oppositional view from another Arab woman named Suha. The latter dislikes Rana's Arab nationalistic appeal and claims that it does nothing except raising more disturbing political debates. She, in addition, situates herself to project her Americanness and align herself with the American mainstream. In other words, Suha generates - by her response - an American nationalism that clashes with Rana's. Suha says: "I don't even know why you expect us to know about all these political things [...] We just want to be Americans like everyone else [...] My brothers and sisters are in Orange County ${ }^{2}$ where they belong" $(2003,191)$. The use of "we" by Suha in this way demonstrates that the Arab American community may be regarded as a multigroup entity characterized by various national loyalties and commitments. The Arab nationalist position as expressed by Rana and the American nationalist reaction as echoed by Suha are two conflicting paradigms exercised by the same community - this adds more complexity in understanding the nature of Arab American identity, its politics, and its intersection with nationalistic ideologies. Suha's counter-nationalism, moreover, given her Arab origin, may validate Fadda-Conrey's statement that "Arab Americans' connections to the Arab world cease to be the ostracizing factor that prohibit them from asserting US belonging" (2014, 3). Crescent, however, situates itself within the Arab nationalist paradigm, given that most Arab American characters in the novel project their attachment, whether directly or indirectly, to their countries of origin in the Middle East. This also suggests that Abu-Jaber shines a light on the politics of Arab nationalism in her novel without excluding other views that can challenge the validity of such nationalism in the Arab American community. In other words, by providing different angles from which to understand how nationalism is negotiated in the diaspora, such as in the cases of Rana and Suha, Abu-Jaber confirms the extent to which the Arab American identity and the sense of belonging are complexly woven.

Equally relevant, in a gathering of some Arab American characters of different national backgrounds for a Thanksgiving celebration, political detestation

2 It is a county located in the Los Angeles metropolitan area in the state of California, USA. 
of American military intervention and policy in Iraq becomes intense. This appears "when Schmaal brings up the U.N. and nuclear weapons inspections, and Gharb talks about the starvation in Iraq and crime and prostitution, and Nathan says that Iraq is suffering pre-famine conditions and is still being bombed regularly by America, who was recently selling them helicopters, and does anyone care" $(2003,221)$. This conversation denotes what Schiller calls an "anti-colonial" long-distance nationalist stance (2005, 574). This stance results in strengthening the connection between Arab Americans and the Arab world, generating transnational vision. Fadda-Conrey, in this context, states that "the US military operations and foreign policies in the Arab world play a direct role in molding a strong transnational consciousness among Arab-Americans" $(2014,8)$. In other words, a transnational outlook becomes another facet that characterizes the notion of long-distance nationalism, cementing a need to revive a strong attachment to Arab homelands and unity with Arab nations.

By the same token, Abu-Jaber showcases such an anticolonial agenda not only through the Arab characters in the diaspora but through non-Arabs too. In a lecture at the Department of Near Eastern Studies, an unidentified man - who seems as a humanitarian activist - leads a discussion to voice his disapproval of American foreign policy and warn of its negative ramifications:

Now, according to UNICEF, fifty thousand Iraqi adults die because of U.S. sanctions every year, and five thousand children die in Iraq every month because of the American embargo of food and medicine. The sanctions deny people access to basic health care, clean water, and electricity - they are a systematic violation of the Geneva Convention, which prohibits the starvation of civilians as a method of warfare [...] America simply cannot continue to pillage the natural resources and economies of other countries, to heap its desire and values, its contempt and greed on the backs of others, and not expect there to be consequences (2003, 324-325).

The narrator describes the speaker's voice as dull and pleasant, especially for Sirine, who approaches the room to see if Han is inside. Such a description of his voice as dull is probably because it conveys the atrocities, and resultant suffering, in recent Iraqi history, and pleasant, due to the way it affects the audience, triggering compassion, sympathy, and emotions. Moreover, it is noteworthy that Abu-Jaber does reproduce a lot of this lecture for the reader. 
Even after Sirine and Han have left the scene, ${ }^{3}$ we hear more of the lecture and the speaker gets increasingly passionate. So there is a sense here that AbuJaber is informing and educating the reader. These narratives, as such, seek interactive engagement and function as a report and a simulation of real-world events - modeling reality in fiction. Raymond Mar and Keith Oatley (2008), for instance, observe that literary stories adopt social information from the real world and frame it with emotions conforming to the events projected by these narratives. Mar and Oatley further argue that "narrative fiction models life, comments on life, and helps us to understand life in terms of how human intentions bear upon it" $(2008,173)$. In light of this, it is possible to argue that Abu-Jaber introduces politics, and the resultant concerns toward the Middle East, in her romantic fiction by using an informative approach consigned to triggering emotions, presenting a reportorial ambition and agenda.

The various political aspirations as echoed in the narrative demonstrate the extent to which Middle Eastern affairs are of great concern to the author, Diana Abu-Jaber, given that the political turmoil in Iraq (1999-2003) accompanied the writing up and production of Crescent. This shows that AbuJaber's nationalistic ideology appears though her use of the novel to talk on behalf of Iraqi nationals and population, although she comes from another country of origin - Jordan. This political solidarity and correlation among Arab members of various nationalities is one of the basic objectives of Arab nationalism. The demonstration of this nationalist ideology in the setting of the diaspora can help the Iraqi cause reach worldwide prominence. Indeed, the Iraqi cause is well apparent in Crescent through a letter sent to Han from his sister who lives in Baghdad. The letter provides a tragic retelling of how Iraq, as a country and population, has sadly been dragged into political turmoil, economic crisis, social instability, and lack of peace and security due to the American military intervention and policies:

Our young women, like our men, march in formation through the streets wearing their veils and carrying long, black guns. Our fine, beautiful country is gone. We can't get away from the smell of burning. Terrible chemical fallout, starvation, no medicine, the usual catastrophe - so dull being a victim. There are many diseases, cholera, malaria, typhus, and rickets. How ridiculous to be struggling with outdated diseases! Our ancient night flashes with bombs. The Americans still bomb Iraq on nearly

3 Sirine, in this scene, seems to lack interest in the speaker's lecture, simply because her attention is on Han, whom she wants to walk with and be with. Sirine, the central character, showing no interest in politics may denote that her romantic affair has priority over the political aspirations in the narrative. This posits more questions about the extent to which her Arab national ties are transparent and reliable. 
a daily basis. I'm told that during the Persian Gulf crisis these displays were compared to fireworks on American television (2003, 176-177).

This letter is not supposed to be found by anyone. It has been tossed into a drawer in Han's room. Sirine's discovery of it comes after her search in Han's personal belongings to feed her own curiosity and also because "she needs to know more about him, to know if it is safe to feel this way about him" (2003, 175). She realizes that "she has never snooped around a boyfriend's room like this before and she is amazed at herself" $(2003,175)$. This shows that the figure of Han to Sirine is not only a lover but a mystery. In her reading of the letter, however, Sirine disregards the dreadful portrayal of Iraq - as told in the above-mentioned passage - and concentrates only on her pursuit to unveil his secrets, especially when the sender of the letter addresses Han as "dear", which adds more suspicions for Sirine that Han has a mistress back home, in addition to the fear that he might have committed a murder when Sirine reads the following line: "There is no way to undo the murder, of course, and we live in fear of Saddam's ruthlessness" (2003, 177). Interestingly, it seems clear, through a critical interpretation of the letter as it appears in the narrative, that the political upheavals in Iraq do not matter to Sirine as they do to Han. One possible analysis of this is that the former, unlike the latter, has not lived or experienced the ravages of war and conflicts in Iraq - she was born in the USA, was acculturated in the USA, and grew up in the USA too; and hence, she lacks a national tie to Iraq, which is her country of origin. This shows that the political concerns and, by extension, nationalist ideology toward the homeland - in the cases of Han and Sirine - are differently negotiated in the diaspora in terms of who have lived in the homeland and who have not. In other words, this difference between Han and Sirine shows that the national consciousness of members of the diaspora varies in accordance to their degree of attachment with the country of origin. In this case, borrowing Anna Triandafyllido's words, "it is important to use different perspectives in order to catch the complexity of national identity dynamics and to account for their multifaceted nature in immigration societies in particular" $(2006,431)$. Abu-Jaber, in this regard, suggests that the narrative moves beyond Sirine's romantic concerns. Abu-Jaber uses the romance as a device for exploring national identity, given that it fulfills the requirements of romantic fiction too. The value of Iraq, as a country and a nation, to both Sirine and Han explains the extent to which national identity in the diaspora can entail heterogeneous perspectives and stances.

The representations of Iraq in the letter in this way, nonetheless, serve to support Fadda-Conrey's statement that the works of Arab American writers 
from the 1990s to the early years of the 21st century "reflect on experiences of displacement, exile, and dispossession caused by the political shifts and military conflicts across the Arab world [...] Such representations, and the political implications they hold, become key factors in shaping the connective and transnational attachments to an Arab homeland" $(2014,20)$. In this respect, it seems possible to situate Abu-Jaber within a group of other diasporic Arab American writers who voice their concerns in their writings about the troubled Arab people and the deteriorating economy and political upheavals in the Arab countries, notably, Randa Jarrar, ${ }^{4}$ Mohja Kahf, ${ }^{5}$ Laila Halaby, ${ }^{6}$ Susan Abulhawa, ${ }^{7}$ and Rabih Alameddine. ${ }^{8}$ This aspect conclusively projects collective solidarity on the basis of shared origins, common descent, and affiliation, and namely, the Arab identity. It should be acknowledged, however, that each novelist may provide different poetics of national identity and various components of collective solidarity, signaling further complexity in understanding the formation of the Arab American diaspora.

\section{Reconfiguration of Stereotypes and Correction of Misrepresentations: A Form of Nationalist Stand?}

Stereotypes, according to Maria Lebedko, "are ubiquitous and typologically greatly vary social, cultural, national, territorial, political, gender, etc. The most harmful, prejudicial, hazardous and dangerous are racial and ethnic stereotypes" $(179,2014)$. Abu-Jaber's resistance to and reconfiguration of stereotypes that characterize the ethnic image of Arabs serve as a critical link to her Arab nationalist paradigm in Crescent, in addition to maintaining the Arabness of her identity. In this context, it should also be acknowledged that 'because stereotypes are based on the distinction between 'us' and 'them', they are also used to create self-images, particularly those related to national identities" (Rezende 2008, 107). In other words, Abu-Jaber's reconfiguration of stereotypes and representations can be interpreted as an apparatus to interrogate the complex binary system of us (Arabs) versus them (white Americans) and correct what represents Arab identity. For instance, the narrator in her novel tells us how Arabs in Um-Nadia's Café are vilified by the US security and services and presumed to be a threat to the American mainstream. This appears through the frequent visits of Central Intelligence

\footnotetext{
4 One of her notable works is A Map of Home (2008)

5 One of her notable works is The Girl in the Tangerine Scarf (2006)

6 One of her notable works is West of the Jordan (2003)

7 One of her notable works is Mornings in Jenin (2011)

8 One of his notable works is Koolaids: The Art of War (1998)
} 
Agency (CIA) men in business suits, who take notes after a skeptical glance at Middle Eastern students and propose an enquiry on any possible "terrorist schemes developing in the Arab-American community" (2003, 21). Such surveillance is referred to by Sirine's uncle as "the Arab disease" (2003, 130), especially when "you keep thinking the C.I.A is following you around" (2003, 130). The label of terrorism, as well as its connection to Arabs, also appears in the media. This is revealed through the commentary of the Egyptian character Jenoob: "All we see on the TV or movies about Arabs is they're shooting someone, bombing someone, or kidnapping someone" $(2003,222)$. Abu-Jaber, through the exploration of such stereotypical attitudes toward the Arabs and Arab American community in her narratives, demonstrates her Arab ethnonationalist voice, which resists the perpetuation of the idea that Arabs, whether in the USA or abroad, are associated with terrorism. She therefore offers a positive image of Arabs, which subverts and corrects the existing negative portrayal of them, strategically. This, for instance, is evident in the opinion of Nathan, a white American student of Middle Eastern Studies, who goes to Iraq to explore the life there and work on his research project. Upon his arrival, he finds himself surprised that people in the Middle East, particularly in Iraq, are different from what the media and popular culture in American mainstream describe. He considers them hospitable gentle people, providing a positive stereotype:

I had this thought about going over to the Middle East and uncovering terrorist spies [...] And when I finally got there, you know, to the Middle East, I travelled through all these different countries, and this amazing thing happened - the people there were really nice to me. They didn't drive around in huge cars talking to each other on phones. They invited me right into their homes. We sipped tea and talked all day long [...] I never found my terrorist (Abu-Jaber 2003, 284).

The resistance to and correction of stereotypes of Arabs and Arab Americans is indeed a nationalist act. The Arab American literary critic Steven Salaita (2007) attests that part of being a nationalist in the USA is to condemn and reprehend misrepresentations. He says: "I would describe myself to a degree as an Arab American nationalist in the sense that I believe strongly in the positive attributes of my community and detest intensely any foolhardy argument that we are innate terrorists worthy of continual surveillance [...] there is nothing mysterious or dangerous about Arab Americans" (2007, 11). However, Salaita also acknowledges that ethnic nationalism provides a narrow definition of Arab American identity, and it reduces the plurality of Arab American experience by focusing on essentialism: "I do believe that ethnic nationalism should be harnessed carefully before it descends into essentialism" 
(2007, 11). As such, Salaita states that, beyond the sensibility of stereotypes and misrepresentations, his ethnic nationalism dissolves. In other words, his ethnic nationalism is limited and restricted only to his concern with the blunt and racist "attitudes gaining credence in the United States that conceptualize Arab Americans as a fifth-column mystery to be treated with wariness and suspicion" (2007, 11). Equally important, Salaita positions himself as an Arab American nationalist, projecting two affiliations that determine his identity. He considers himself an Arab national as much as an American national. The question of nationalism in this case intersects with the definition of hybridity. This demonstrates the idea that the politics of nationalism in the diaspora in the case of Arab Americans - entails complex structures and definitions. Salaita's point of view of the intersectionality between ethnic nationalism and the subversion of stereotypes in the setting of diaspora, furthermore, is apparent in the novel through Gharb, an Egyptian student, and Sirine's uncle. The former says: "The Americans need to hear our poetry and stories and this and that sort of stuff" $(2003,222)$. The latter, rephrasing Um-Nadia's words, proclaims that "Americans need to know about the big, dark, romantic soul of the Arab" $(2003,222)$. Both characters in this regard endeavor to humanize the Arabs and provide a positive image of them, generating an ethnic nationalist stance by which to overturn, and also to challenge, the existing misrepresentations in the American popular mainstream.

By the same token, in her introduction to Food for Our Grandmothers: Writings by Arab-American and Arab-Canadian Feminists (1994), Joanna Kadi comments on the term "Arab-American" as suggestive of nationalist ideology. She argues that, regardless of the tension between the two hyphenated terms, the implementation of "Arab" with "American" strategically contributes to the overturning of racist and negative views toward Arabs. In this respect, she says that the term "Arab-American" "allows us to reclaim the word Arab, to force people to hear and say a word that has become synonymous with 'crazy Muslim terrorists'. It affirms our identity and links us to our brothers and sisters in Arab countries" (xviii). The link that Joanna Kadi refers to is a manifestation of a long-distance nationalist position that affirms a claim to Arab identity across borders. Kadi's reflection defines such nationalism as "a set of identity claims and practices that connect people living in various geographical locations to a specific territory that they see as their ancestral home" (Schiller 2005, 570).

In addition, the process of challenging the stereotypes of Arabs is further demonstrated through Rana, a liberal Saudi-American woman, who escapes the oppression of her controlling husband in Saudi Arabia and comes to the 
USA. She breaks the confinements of her past life and then starts to sleep with Aziz to unleash her sexual desire liberally (2003, 316-317). She becomes a woman that Sirine admires because of her fierce mind, strong political stance, and intelligence: "In her presence, Sirine feels as if her own mind is a small, dimly lit place" (2003, 192). Rana's personality can be regarded as the other part that Sirine's character lacks in her pursuit to locate herself socially and culturally. The latter is reduced in the former's presence to suggest that characters in the narrative construct complementary relationships. In other words, a heroine, in the case of Sirine, can sometimes never be complete, but other characters, in the case of Rana, can provide an alternative version of how a heroine should be. The portrayal of Rana in that way, moreover, is an attempt by Abu-Jaber to subvert and correct the stereotypes that circumscribe the veiled Arab Muslim women as the exotic, the passive, and the repressed. This suggests that the veiled woman can also be regarded as a strong feminist, despite certain cultural and religious complexities. Resisting and correcting the negative image of the Arabs - both men and women - seem to be the primary agendas behind the writing of Crescent. It groups Diana Abu-Jaber with Steven Salaita and Joanna Kadi. Accordingly, in a discussion about her fiction, Abu-Jaber openly addresses this objective to her interviewer Robin Field when she says:

If there's any social agenda in what I do, that is probably the number one thing: trying to counteract the media portrayals-the terrorist for the Arab man and the oppressed, hidden, exotic Arab woman. I talk about them in terms of diversity and humanity. I think the best way that comes through is by addressing vulnerability (2006: 219).

The projection of Arab national identity by resisting and correcting the negative stereotypes of Arabs, whether for humanity or diversity reasons - as explained in Abu-Jaber's terms, posits a particular solidarity with the Arab nation. By the same token, Abu-Jaber challenges the rise of negative conceptualizations of Arabs as extremist, barbaric, and violent, resulting from the geopolitical landscapes and crises in the Arab world, such as the Iraq-Iran war in the 1980s, the Iraq-Kuwait war in the 1990s, the Arab oil embargo in the 1970s, the Arab-Israeli Wars in 1967, and the Gulf War in the 1990s (Fadda-Conrey 2014, 2). She positions herself to voice her Arab national identity by resisting such conceptualizations on behalf of Arab communities across the borders, particularly in the USA. An example of these communities is the Iraqi. She, for instance, introduces the Arab society in Iraq through Nathan's overwhelming description, on the basis of the wars that afflicted Iraq, and the role of the US media to vilify the people in Iraq. Nathan says: 
The people in Iraq - this sounds dumb and romantic - but the thing is, they really seemed to know who they were. They dressed the way their grandparents dressed, they ate the way they've eaten for hundreds of years. And they were so alive - I mean, lot of them didn't have TV or telephones, but everyone talked about politics, art, religion, you name it. They were living under dictatorship but their inner selves stayed alive - do you see. (2003: 99)

On the basis of Nathan's words, it is possible to argue that Abu-Jaber's implicit Arab national identity in her writings is also expressed from a humanitarian and sympathetic perspective, drawing a line between the very normal spontaneity and the mere reality of Iraqi people and what American popular culture holds of them. In other words, humanism and sympathy comprise much of Abu-Jaber's Arab national identity, establishing a sense of solidarity. It is noteworthy to acknowledge that, in addition to Abu-Jaber's Crescent, other Arab American creative productions also have the agenda to resist and correct the stereotypes that define Arabs in the USA and their national characteristic - an example of such productions is drama. Suaad Alqahtani, for instance, states that Arab American playwrights "have introduced performances on the American stage that dispel the recurrent image of the vicious Arab. They attempted to replace the stereotypical monolithic perception of Arabs/Muslims with a more humanized portrait" $(2018,394)$. This shows that overturning the stereotypes and misrepresentations that categorize and characterize the Arab community in the USA in particular, and in the Arab nation in general, becomes the prioritized concern and objective in both written and performed works of Arab Americans, especially in the post-9/11 period.

\section{National Identity Markers in Diaspora: Language, Religion, and Memory}

"Arab nationalism" as a term and concept, in Peter Wien's opinion, "presents nationalism as an experienceable set of identity markers - in stories, visual culture, narratives of memory, and struggles with ideology, sometimes in culturally sophisticated forms, sometimes in utterly vulgar forms of expression" (2017, I). As such, these identity markers constitute a nationalist paradigm that shapes collective identities and brings community members together. Indeed, the identity markers that project the nationalist stance appear in the setting of the Arab American diaspora, as shown in Crescent. This includes the Arabic language (linguistic practice), fasting (Islamic practice), Arab food and Arabic music (Arab cultural celebration), and memory (images of the homeland). Abu-Jaber - apart from the food and music that also form part of nationalism (Wien 2017, 86-87; Brincker 2014) - focuses on how the Arabic language and religion of Islam are practiced to denote a belonging to the Arab 
nation and how memory functions to express one's own nationalism in the diaspora. In Gabriella Elgenius's opinion, "a working definition of nation will refer to the imagination of community in terms of shared cultural, political and socio-economic elements (such as history, language, religion, ethnicity, territory, attainment of recognition)" $(2011,7)$.

In terms of Arabic language, Samir Bitar reminds us that the demonstration of nationalist propensities can include a linguistic form (Bitar 2011). Similarly, Albert Hourani suggests that nationalism derives its power from a practiced common language; it is based on the idea that "all who spoke the same language constituted a single nation and should form one independent political unit" (1993, 341-342). The practice of and conversations in the Arabic language among the Arab American characters in Crescent often appear in Um-Nadia's Café $(2003,19-24)$. The cafe is a place that demonstrates the Arabic language in many forms, through the scattered Arabic newspapers, the Arabic TV channels that run all day $(2003,354)$, or the loud political arguments in Arabic by young men from Arab countries (2003, 215-337-338). The Arabic language thus can be regarded as an ethno-symbolic feature of Arab national identity in a diaspora, which, in this regard, is understood as an "assertion of belonging in and to a place, a people, a heritage" (Said 2000, 176). Indeed, the assertion of belonging to the Arab nation and heritage can be exemplified by Sirine's attempts to learn Arabic to both read Arabic news (which she regularly struggles to understand) and communicate well with other fellow Arabs. She therefore asks Han to teach her Arabic. The narrator tells us that "she grew up around Arabic conversations and she feels the presence of Arabic somewhere behind her mind, like a ghost language - crisp, clear, and oceanblank. And she feels guilty that she can't speak it" $(2003,131)$. This posits a critical interpretation that Arabic language serves as an effective medium for Sirine to strengthen the ties with kin Arab communities inside the USA and facilitate the construction of her Arab national identity in the diaspora.'

Interestingly, the grandeur of the Arabic language appears in the narrative through Han's speech, when he introduces Abdo Aziz, a poet and a visiting writer, at a reading session. Han links Aziz's complacence to the nature of the Arabic language as the following passage shows:

Abdo transforms Arabic, he understands its deepest, hidden nature, its possibilities, he forces the language, as one might force a spring

9 Given that Sirine also endeavors to assimilate into the US mainstream, learning the Arabic language might be seen as a way for Sirine to "better" assimilate into the Arab community too and engage with it. This can be understood as nothing but an extension of Sirine's hybridity. For more reading about the relationship between hybridity and Arab American characters in fiction, please see, notably, Steven Salaita's Arab American Literary Fictions, Cultures, and Politics (2007). 
planting into its richest, most vital profusion and budding. He tends to this deep, powerful language, nudging seedlings to light. To quote the historian Jaroslav Stetkevych on Arabic, "Venus-like, it was born in a perfect state of beauty, and it has preserved that beauty in spite of all the hazards of history.... It has known austerity, holy ecstasy and voluptuousness, boom and decadence. It exuberated in times of splendour and persisted through times of adversity in a state of nearhibernation. But when it awoke again, it was the same language" $(2003,29)$.

Han's poetry-like introduction fascinates Sirine, who regards him with a romantic gaze and as a figure who reminds her of her father. The narrator tells us that she was "caught up in his rapturous speaking. She has never heard anyone speak so eloquently and longingly of Arabic before" $(2003,30)$. The portrayal of Arabic language by Han in this way, moreover, demonstrates its central significance to Arab heritage and culture, as well as for their (Arabs) collective identity. In other words, it seems, to some extent, that Han romanticizes the Arabic language probably because he is proud of it. It signifies his origin and identity and projects the politics of sameness with other members of the Arab American community or the Arab nation abroad. In this context, Yasir Suleiman believes that language is the most essential feature of group identity. He states that "the treatment of language as the core ingredient and the most prominent manifestation of nationalism is characteristic of Arabic discourse on this topic [of the importance of Arabic to Arab identity]" (1994, 3). Equally important, the narratives in Crescent project several "transliterations" of Arabic words into English. Abu-Jaber inserts many Arabic words in her writing, such as Khullus $(2003,254){ }^{10}$ habeebti (2003: 253), ${ }^{11}$ hejjab (2003: 255), ${ }^{12}$ Imshee (2003: 338) ${ }^{13}$, Id-al-Fitr (2003, 383), ${ }^{14}$ Alhumdullilah (2003: 389), ${ }^{15}$ and sometimes even long phrases such as Kitab al-Wusla Ila' L-Habib, which means The Book of the Link with the Beloved (2003, 386). This transliteration might be understood as a projection of Abu-Jaber's assertion of her belonging to the Arab nation and community, offering a translation of her ethnicity through such ethnic cultural form. With respect to Abu-Jaber's implementation of the Arabic language through transliteration in her narratives, Yasir Suleiman argues that "whether

\footnotetext{
10 Means "Enough" in English.

11 Means "Beloved" in English.

12 Means "Veil" in English.

13 Means "Go" in English.

14 Means "Fast-Breaking" in English.

15 Means "God's blessings" in English.
} 
objectively or subjectively defined, and whether or not one characterizes it in boundary or ethno-symbolic terms, the nation is often associated with language as a marker of its identity" $(2003,27)$. This suggests that DianaAbu Jaber, as an Arab American author, participates in the formation of Arab national identity in the setting of the diaspora, bridging Arab communities together on the basis of the Arabic language. In other words, she maintains the idea that there is a strong association between national identity and language, given that most transliterations in the narrative appear when Arab characters are grouped together or attempt to manifest a cultural practice collectively. She seems to conclude that, borrowing Suleiman's words, "language is the medium which makes the nation as 'an imagined community' imaginable. It connects the individual in social time and social space to fellow nationals whom he or she will never hear of, meet or know" (2003, 30).

In addition to the Arabic language, the religion of Islam also has a role in endorsing Arab nationalism in a diasporic context. Given that Abu-Jaber's Crescent is considered a piece of postmodern fiction (Yousef 2010), Mark Juergensmeyer asserts that "increasingly religious identities and ideologies have become the basis for strident new forms of nationalism and transnationalism in a globalized, postmodern world" (2006, 269). Regardless of this, it should be acknowledged that Arab nationalism can also be examined from a secular point of view. ${ }^{16}$ This is because not all Arabs are Muslims. Some secular Arabs do not acknowledge religious affiliations but still opt for an Arab national assembly and unity (Wien 2017, 9-11). In fact, one of the main tenets of nationalism is that it entails a secular ideology - pertaining loyalty to humanity not religion - and "it has no place for the divine" (Smith 2009: 75). However, in the context of Crescent or other Arab American novels, most Arab characters in the US diaspora are Muslims. Their "Muslimhood", whether practically or virtually, acts as a reinforcement of their allegiance and unity among themselves or with others abroad. Smith et al. (2010) assert that religion has a significant role in shaping nationalism in the diaspora, especially if that diaspora operates in a pluralistic country - in the case of Arab Americans, the USA. According to them, "when diaspora nationalism is meaningfully at home in a pluralistic host country, its religion may work as an associated moderate and enlightened factor" (2010, xvi). In other words, religion can facilitate the construction of nationality and thus bridges a diaspora to its original homeland.

16 Juergensmeyer Mark explains that secular nationalism has increasingly been critiqued in the Arab world, particularly the Middle East, in the modern era for three essential reasons: it is regarded as a Western intrusion, it is intolerant of religion, and it promotes a unified world order that encourages a single central political authority (2006: 271-272). 
Building on the argument of Smith et al. (2010), it is possible to argue that religion features Arab national identity in the host country, the USA, as a Janus-faced entity. For instance, on the one hand, it contributes to projecting a certain degree of commonality within the group that binds its Arab members together. On the other hand, it shows that national identity implies difference. From Anna Triandafyllido's perspective, immigrants' national identity in the country of settlement, "involves both self-awareness of the group but also awareness of others from whom the nation seeks to differentiate itself" (2006, 421) - in this case, white Americans. In other words, the Arab community in the novel utilizes religion to both express their national identity and draw a line from the national majority in the host country. For instance, celebrating Ramadan, as an Islamic practice and tradition, maintains the Arab characters' Islamic affiliation and their ties to the Arab nation. Ramadan is a month of fasting that Arabs celebrate to fulfill their duty to Islam and the deity. In his storytelling, Sirine's uncle reminds us how the month of Ramadan is observed:

The Prophet Muhammad, peace be upon him, told his followers to time certain rituals and activities according to the new moon. The first sighting of the new moon marks the beginning of each Islamic month and it marks the end of Ramadan - the great and pious month of fasting - which closes with "Id-al-Fitr, the Feast of Fast-Breaking" (2003, 383).

The practice of this Islamic obligation works beyond just simply religious objectivity. It also determines the process of inclusiveness in the forming of a national identity on the basis of such religious practices. ${ }^{17}$ The gathering at UmNadia's Café to celebrate Ramadan includes Arabs of different nationalities, such as Saudis, Palestinians, Lebanese, Iraqis, Egyptians, and Kuwaitis, among many others. ${ }^{18}$ Interestingly, projecting Arab national identity also becomes part of a wider national paradigm, which entails religion as its core - Muslim nationalism. This happens particularly in the month of Ramadan, when Muslims all over the city, such as Iranians, Pakistanis, Malaysians, and Croatians, come to the cafe to share with the Arabs a celebration of this holy month. Religion thus performs as a key factor that forms two distinctive but

17 For further understanding of the relationship between religion and nationalism, see, notably, Barbara-Ann Rieffer's article "Religion and Nationalism: Understanding the Consequences of a Complex Relationship" (2003).

18 It should be acknowledged in this context that some characters, such as Um-Nadia, are non-Muslim but, still, they opt to be part of such a religious manifestation because of their tie to the Arab identity and nationalism, and also, because of the willingness to be grouped with other fellow Arabs in the diaspora. This shows that celebration of the national identity supersedes many other aspects, regardless of difference or diversity. 
interrelated types of nationalism - Arab and Muslim - and as a criterion of identification to strategically politicize the process of inclusion. This, to a large extent, reflects Pappe Ilan's understanding of the notion of national identity. According to him:

National identity whether imagined, engineered or manipulated, is a recent human invention born out of the integration of conflicting ethnic or cultural identities or the disintegration of such identities. It is a modern invention of an axis of inclusion and exclusion that is not organic or natural thus requiring the artificial identification of those who belong to the nation, and more importantly, those who are excluded from it $(2006,755)$.

By these words, Pappe Ilan suggests that the formation of the national self becomes critical in the formation of otherness on the basis of inclusion and exclusion parameters. Religion, therefore, can be regarded as an essential parameter that defines the "other". The impact of religion on forming nationalism furthermore appears in the narratives when Sirine asks Han whether he is a Muslim. The latter claims that he is not a believer anymore, but still, he considers himself a Muslim for an important cause, to maintain political, social, cultural, and national objectivities: "I am no longer a believer but I still consider myself a Muslim. In some ways, my religion is even more important to me because of that [...] I do believe in social constructions, notions of allegiance, cultural identity" $(2003,182) .{ }^{19}$ Han's reply supports the opinion of both Barbara-Ann Rieffer (2003) and Rogers Brubaker (2012) that there is a strong interplay between nationalism and religion. The intersection between religion and nationalism, according to Mark Juergensmeyer, increased rapidly by the beginning of the 21st century despite the repercussions of globalization, which is marked by "a rapid mobility of peoples, mass migrations, the proliferation of diaspora cultures, and a transnational sense of community" $(2019,1)$. Han's religious overtones are also apparent by his constant use of Islamic beads to not forget saying his prayers and to maintain his piety. In fact, given that his nationalist propensity in the diaspora mostly concerns Iraq and its nation, Rieffer asserts that Iraqi nationalist ideology, to the present, is religion-related and notably holds "instrumental pious nationalism" (2003, 224), which incorporates religion "as a supporting element that can unite a population" (2003, 224-229). His Muslimhood, however, probably not only functions to project his nationalist thinking and national identity but also to

19 Han's reply may also be interpreted as an implicit opposition to the nationalist vision that Saddam Hussein built on the basis of secular political principles. The latter, as Mark Juergensmeyer (2010) contends, was in favor of secular nationalism and was regarded as the enemy of Islam. For more details, see "The Global Rise of Religious Nationalism", Australian Journal of International Affairs, 64(3), 262-273. 
alleviate the burden of his experience of exile and keep his attachment to the homeland alive.

Han's national identity, moreover, can be best described by what Khachig Tololyan calls "exilic nationalism", which concerns people who are coerced to leave their homelands and opt to maintain their nationalist position in the host country $(2010,33)$. Accordingly, maintaining exilic nationalism, in Tololyan's opinion, requires certain features that represent one's national identity and sustain attachment to the homeland: these include language (Arabic), religion (Islam), and duty (2010, 34). Interestingly, Han's nationalist duty first appeared when he was in Iraq - his opposition to Saddam Hussein's dictatorship seemed to him a service to his country and the repressed Iraqi people: "I sank myself into politics [...] publishing diatribes against Saddam Hussein in underground newspapers. I wrote under pseudonym, Ma'al - I thought it sounded dangerous and mysterious" $(2003,329)$. Han is politically engaged to the extent that he would be executed if he returns to Iraq - he was regarded as a political menace to Saddam Hussein's system. This political opposition and nationalist stance become part of Han's life in the diaspora and an extension of his exilic experience. In other words, Han's stance toward the ruling regime in Iraq perpetuates long-distance nationalism. According to Glick Schiller, a central component of long-distance nationalist thought is "regime change" $(2005,574)$. Han's reflections generate the idea that exile nourishes nationalism. For Edward Said, both are two faces of the same coin and serve complementary relationship. He opines that "the interplay between nationalism and exile is like Hegel's dialectic of servant and master, opposites informing and constitutes each other" (2000, 208).

Additionally, a nationalist position in the diaspora can also be reinforced by memories of home - whether cultural, political, national, or historical. Memories, in Khatharya Um's terms, "nurture long-distance nationalism and spur transnational activism" (2019, 329). They have multiple functions, but notably, a reminder of one's own original belonging to a particular nation or country. In the context of nationalism, memories can trigger willingness to show unity and solidarity, as well as engage in activism, with fellow nationals in the setting of both the diaspora and the homeland. According to John Brewer, "nations and memories are indivisible" $(2006,318)$. In the case of Han, his memories rely on invoking symbolic aspects of his country, i.e., Iraq, and the physical picture of it. This is evident in his conversation with Sirine who "asks about his parents and his memories of school and friends":

He comes up with chips of details, bits of recollections of the chalky roads in their village, the grassy green olive oil on their kitchen table, 
and the coal-colored falcon that haunted a tree beside their house. He tells her about going to the desert that started just a few miles from his uncle's farm - the same desert he would eventually cross when he fled Baghdad. (2003, 208-209)

Han, in this passage, offers a historical narrative of the past by which to establish a sense of his nationhood in the setting of exile, in the US diaspora. Its construction relies on remembering what John Brewer calls features of nationhood: "physical and symbolic places, landscapes, cultural and historical sites and events that constitutes the nation" $(2006,318)$. This is also apparent through his portrayal and remembrance of three prominent national symbols of Iraq and its history: the Euphrates and the Tigris rivers; and the Hanging Gardens of Babylon (2003, 82). Gabriella Elgenius (2011), for instance, explains that national symbols are central markers of unity, nation-building, and nationalism. According to Elgenius, national symbols function "to express complex meanings related to nationhood and are for this reason challenged, contested, disputed, negotiated, mobilized, and replaced during socio-political conflict" $(2011,2)$. In this sense, Han's remembrance of Iraq as such, with regard to his sociopolitical status, might work to fill that gap in his life that results from his displacement and his nationalist enthusiasm against Saddam Hussein's regime.

The key feature of Han's personal memories is that they produce social correlation and fusion, promoting collective national identity. This is because, as John Brewer argues, "personal memories exist in relation to the social processes that occasion and shape them, such as language, nationalism, cultural and political symbols and alike" $(2006,317)$. On this basis, it could be argued that "the strong and interdependent links between nationalism, identity, and memory materialize in the sites and rituals of commemoration, where the national movement fuses and molds the collective memory into collective identity" (Gershoni 2006, quoted in Litvak 2009, 14). Memory, therefore, contributes to the construction of nationalism for diasporans in the same way that language and religion do, generating a long-distance nationalist stand. Abu-Jaber, in this regard, points out that nationalism in the diaspora drawing on the experiences and perspectives of the Arab American characters - implies the construction of a strong identity, as well as the establishment of strong political, social, and cultural ties between the Arab community of immigrants in the USA and the Arab mother-nation abroad. She, in this respect, paints a clear picture of what constitutes national identities in the diaspora - long-distance nationalism. The components of long-distance nationalism - such as language, religion, and memory - contribute to the formation of the Arab American community. This, in effect, complicates the 
Arab Americans' affiliation to and their citizenship of the USA, which were initially put into question "since the arrival of the first wave of immigrants from the Arab world in the nineteenth century" (Fadda-Conrey 2014, 4).

\section{References}

Abu-Jaber, Diana. 2003. Crescent. New York: Norton \& Company Ltd.

Alqahtani, Suaad. 2018. "Post-9/11 Arab American Drama: Voices of Resistance in Back of the Throat and Browntown". Journal of Muslim Minority Affairs. 38(3). 392-408.

Anderson, Benedict. 1994. "Exodus". Critical Inquiry. 20(2). 314-327.

Anderson, Benedict. 1998. The Spectre of Comparisons: Nationalism, Southeast Asia, and the World. London: Verso.

Barbara-Ann, Fierre. 2003. "Religion and Nationalism: Understanding the Consequences of a Complex Relationship”. Ethnicities. 3(2). 215-242.

Bordes-Benayoum, Chantal. (2020). Contemporary Diasporas, Nationalism, and Transnationalim Politics. In Allon, G. Athena, L. Anthony, S. The Call of the Homeland: Diaspora Nationalism, Past and Present (pp. 47-61). Boston: Brill.

Bitar, Samir. 2011. "Language, Identity, and Arab Nationalism: Case Study of Palestine". Journal of Middle Eastern and Islamic Studies (in Asia), 5(4): 48-68.

Brewer, John. 2006. "Memory, Truth and Victimhood in Post-Trauma Societies". In Delanty, Gerard., Krishan Kumar, ed.. Handbook of Nations and Nationalism. Thousand Oaks: SAGE Publications.

Brincker, Benedikte. 2014. "The Role of Classical Music in the Construction of Nationalism: A Cross-National Perspective". Nations and Nationalism. 20(4). 664-682.

Brubaker, Rogers. 2012. "Religion and Nationalism: Four Approaches". Nations and Nationalism. 18(1). 2-20.

Elgenius, Gabriella. 2011. Symbols of Nations and Nationalism: Celebrating Nationhood. Hampshire: Palgrave McMillan.

Fadda-Conrey, Carol. 2014. Contemporary Arab-American Literature: Transnational Reconfigurations of Citizenship and Belonging. New York: New York University Press.

Gershoni, Israel. 2006. Pyramid for the Nation: Commemoration, Memory, and Nationalism in Twentieth Century Egypt. Tel Aviv: Am Oved.

Hourani, Albert. 1993. Arabic Thought in the Liberal Age: 1798-1939. Oxford: Oxford University Press.

Ilan, Pappe. 2006. "Arab Nationalism”. In Delanty, Gerard and Krishan Kumar, ed. Handbook of Nations and Nationalism. Thousand Oaks: SAGE Publications.

Juergensmeyer, Mark. 2019. "Religious Nationalism in a Global World". Religions. MDPI. 97(10). 1-8.

Kadi, Joanna. 1994. Food for Our Grandmothers: Writings by Arab-American and Arab-Canadian Feminists. Boston: South End Press.

Landau, J. 2001. “Diaspora nationalism”. In Encyclopedia of Nationalism, ed. A. S. Leoussi. New Brunswick (USA) and London (UK): Transaction, 46-50. 


\section{Journal of Nationalism, Memory \& Language Politics 15(1)}

Lebedko, G. Maria 2014. "Interaction of Ethnic Stereotypes and Shared Identity in Intercultural Communication”. Procedia - Social and Behavioral Sciences. 179-183.

Litvak, Meir. 2009. Ed. Palestinian Collective Memory and National Identity. New York: Palgrave McMillan.

Mar, Raymond., Oatley Keith. (2008). "The Function of Fiction is the Abstraction and Simulation of Social Experience”. Perspective on Psychological Science. 3(3). 173-192.

Mark, Juergensmeyer. 2006. "Nationalism and Religion". In Delanty, Gerard and Krishan Kumar, ed.. Handbook of Nations and Nationalism. Thousand Oaks: SAGE Publications.

Miscevic, Nenad, "Nationalism”, The Stanford Encyclopedia of Philosophy (Summer 2018 Edition), Edward N. Zalta (ed.). https://plato.stanford.edu/entries/nationalism/

Misra, Amalendu. 2003. "A Nation in Exile: Tibetan Diaspora and the Dynamics of Long Distance Nationalism”. Asian Ethnicity. 4(2). 189-206.

Rezende, Claudia Barcellos. 2008. "Stereotypes and National Identity: Experiencing the Emotional Brazilian”. Identities: Global Studies in Culture and Power. 15(1). 103-122.

Salaita, Steven. 2007. "Searching Diversities: Observations of an Arab Ex-student”. In Arab American Literary Fiction, Cultures, and Politics, 1-17. New York: Palgrave McMillan.

Salaita, Steven. 2011. Modern Arab American Fiction: A Reader's Guide. New York: Syracuse University Press.

Said, Edward. 2000. Reflections on Exile and Other Literary and Cultural Essays. London: Granta Books.

Schiller, Nina Glick., Fouron, Georges Eugene. 2001. Georges Woke Up Laughing: Long-distance Nationalism and the Search for Home. Durham: Duke University Press.

Schiller, Nina Glick., Fouron, Georges Eugene. 2001. Georges Woke Up Laughing: Long-distance Nationalism and the Search for Home. Durham: Duke University Press.

Schiller, Nina, G. 2005. "Long-distance Nationalism”. In Encyclopedia of Diasporas: Immigrant and Refugee Cultures Around the World, 570-580, (Eds). Ember Melvin, Ember Carol, and Skoggard Ian. Boston: Springer.

Schiller, Nina, Glick. 2005. “Long-Distance Nationalism”. In Encyclopedia of Diasporas, (ed), Ember M., Ember C.R., Skoggard I. Boston: Springer.

Smith, Anthony. Ethno-symbolism and Nationalism: A Cultural Approach. New York: Routledge.

Smith, Anthony., Leoussi, Athena., Gal, Allon. 2010. The Call of the Homeland: Diaspora Nationalisms, Past and Present. Boston: Brill.

Suleiman, Yasir. "Nationalism and the Arabic Language: A Historical Overview". In Arabic Sociolinguistics: Issues and Perspectives, ed, Yasir Suleiman. Surrey: Curzon Press.

Suleiman, Yasir. 2003. The Arabic Language and National Identity: A Study in Ideology”. Edinburgh: Edinburgh University Press.

Tololyan, Khachig. 2007. "The Contemporary Discourse of Diaspora Studies”. Comparative Studies of South Asia, Africa and the Middle East. 27(3): 647-655.

Triandafyllido, Anna. 2006. "Nations, Migrants and Transnational Identification: An Interactive Approach to Nationalism”. In Delanty, Gerard and Krishan Kumar, ed. Handbook of Nations and Nationalism. Thousand Oaks: SAGE Publications. 
Berrebbah

The Mosaics of National Identity in the Arab American Diaspora ...

Um, Khatharya. 2019. "Diasporas and the Politics of Memory and Commemoration”. In Routledge Handbook of Diaspora Studies. Ed, Cohen and Fischer.

Wien, Peter. 2017. Arab Nationalism: The Politics of History and Culture in the Modern Middle East. New York: Routledge.

Yousef, Tawfik. 2010. "Diana Abu-Jaber's Crescent as a Postmodernist Novel”. Dirasat: Studies in Human and Social Sciences. 37(1). 228-244. 